九州大学学術情報リポジトリ

Kyushu University Institutional Repository

\title{
Rice Production and Processing in Northern Vietnam : A result of field survey in Yen My Town, Hung Yen province
}

Nguen Thi Minh Hien

Laboratory of Quantitative Analysis of Agribusiness organization, Division of Industrial Organization of Agribusiness, Department of Agricultural and Resoruce Economics, Graduate School of Bioresoruce adn Bioenvironmental Sciences, Kyushu University

Kawaguchi, Tsunemasa

Laboratory of Quantitative Analysis of Agribusiness Oragnization, Division of Industrial Organization of Agribusiness, Department of Agricultural and Resource Economics Faculty of Agriculture, Kyushu University

https://doi.org/10.5109/4550

出版情報: 九州大学大学院農学研究院紀要. 48 (1/2)，pp.271-288，2003-10-01. Faculty of Agriculture, Kyushu University

バージョン :

権利関係 : 


\title{
Rice Production and Processing in Northern Vietnam -A result of field survey in Yen My Town, Hung Yen province-
}

\author{
NGUYEN Thi Minh Hien* and Tsunemasa KAWAGUCHI \\ Laboratory of Quantitative Analysis of Agribusiness Organization, Division of Industrial \\ Organization of Agribusiness, Department of Agricultural and Resource Economics \\ Faculty of Agriculture, Kyushu University, Fukuoka 812-8581, Japan
} (Received April 14, 2003 and accepted may 12, 2003)

\begin{abstract}
Agriculture in Vietnam is now in the course of restructuring (Izumida, et al., 2000), and marketing system of farm household products is gradually and steadily transforming (Kawaguchi, 2003). We are interested in making clear the historical process of transformation of marketing system of farm household products in Vietnam both empirically and theoretically. But we have not enough basic data in hand for such study. In this paper we try to make some basic data for marketing system of rice in Vietnam. Seventy households consisting of 30 rice-growing households, 5 collecting households, and 35 milling and processing households were surveyed by interview method in Yen My Town- Hung Yen Province, a big rice trading and processing centre in the North.

Collecting households operate in quite big regions that cover many provinces of Red River Delta, of central coast and of Mekong Delta. Each household buys in average per year a volume of 770.5 tons of paddy and 906.5 tons of milled rice. Their main obstacles are poor storing condition, lack of funds, and lack of market information. The average rice processing capacity of milling and processing household is 3366.67 tons, 1666.75 tons, and 1139 tons per year for large, medium, and small-scale plants respectively. Lacks of available credits, low rice price, restriction of capacity of power line, narrow surface area used for processing are also contributing to the difficulties in rice processing.
\end{abstract}

\section{Introduction}

Red River Delta is the second largest rice producing basin of Vietnam. It covers 9 provinces and cities with the total area of 1266.3 thousand hectares. It was created by alluvial soil of the Red River (Song Hong), Thai binh River (Song Thai Binh), and Duong River (Song Duong). Because of high population density, the average area per capita is only $591 \mathrm{~m}^{2}$, the lowest of the nation (GSO 2000).

Due to small rice growing area per capita, high population, labor surplus with high unemployment rate, and undeveloped rural markets, the living standard of rural farmers is low and in difficulty. Therefore, the development of rural traditional industries and trade is necessary to create jobs and improve the living standard for farmers.

Yen My town has a long history of rice trading and rice milling and processing. Recently, the living standard of Yen My people has been gradually improved. With the

\footnotetext{
* Laboratory of Quantitative Analysis of Agribusiness organization, Division of Industrial Organization of Agribusiness, Department of Agricultural and Resource Economics, Graduate School of Bioresource and Bioenvironmental Sciences, Kyushu University

+ Corresponding author (E-mail: nthiminhien@yahoo.com)
} 
help of transportation business, rice trading and milling and processing has became a good source of income for local farmers. Therefore, Yen My district was selected as a case study site for our research. General objective of study is to make basic data for trading, processing, and marketing of rice in the North of Vietnam. The result of study could be good reference in providing useful data and information to understand the rice farming and marketing system of Vietnam. Moreover, it can be clear evidence of the large interregional marketing networks, especially between Mekong Delta and other regions in the North.

The main method to collect information for this research was direct interview through a set of questionnaires. In order to get the accurate information and more data, consultation with local government officials also was implemented. The questionnaires focused mainly on the current production situations of household such as general information about household and household head, education level, experience in production and business, labor use, income and source of income of household, asset and financial capital status to support rice production and processing. Then the current situation of rice production and processing, the product marketing system, activities of supporting organization such as agricultural cooperatives, rural credit system, agriculture extension system, and finally, problems, difficulties that affect rice production, trading and processing at the local are also be exploited.

Table 1. Number of surveyed households in Yen My town (unit: household)

\begin{tabular}{lrccccc}
\hline Type of HH & Total & $\begin{array}{c}\text { Trai } \\
\text { trang }\end{array}$ & Do Xa & Ong To & Dong La & $\begin{array}{c}\text { Nghia } \\
\text { trang }\end{array}$ \\
\hline 1. Rice growing HH & 30 & 6 & 6 & 6 & 6 & 6 \\
2. Rice collecting HH & 5 & 1 & 1 & 1 & 1 & 1 \\
3. Rice milling HH & 35 & 12 & 5 & 8 & 5 & 5 \\
$\quad$ Total & 70 & 17 & 10 & 13 & 10 & 10 \\
\hline
\end{tabular}

Through observations, the households participating to the rice production, trading and processing were classified to the rice-growing household, rice collecting household, and rice milling and processing household. The total number of households studied was 70 , of which there were 30 rice-growing households, 5 rice-collecting households, and 35 rice milling/processing households. Table 1 shows the breakdowns of types of those farming households in Yen My.

Those 30 rice-growing households were categorized into three groups as high-income, medium-income, and low-income households. The classification was based on the information of the Ministry of Labor, Invalid and Social Affair. Besides, classification was also based on local criteria of Hung Yen province and Yen My town. In the sample, the number of household in each group were selected proportionally to real proportion of high, medium, and low income households in Yen My town in order to ensure truly representative sample of population as a whole.

Rice milling and processing households were categorized by size. In this case, the category was defined only relatively. Households with large-scale plants were those that had modern machinery and some had facilities from cleaning, drying, sizing and polishing. 
Large mills have capacities of over 10 tons/day. They also participated in rice collecting activities. Households with medium scale plants had small rice milling and processing equipments. Medium mills process about 4-10ton/day. For those with small-scale plants, they had only small rice milling machines. Small mills handle less than 4 ton/day. Typically, these mills remove the husk and part of the bran, but do not have facilities as larger mill plant, and mostly to serve farmers in the local area.

\section{General background of Yen My}

Yen My town is located in the south of My Van district, Hung Yen province. It is about 4 kilometers from the district center, with an area of 407.91 hectares. Yen My can be viewed as main access point for transportation connected to National Route $5 \mathrm{~A}$ to the center of Hung Yen province. It has 2 kilometers of provincial route $39 \mathrm{~A}$ crossing the district center. The transportation networks connecting the district with other districts in the area, and other vicinity provinces such as Thai Binh, Ha Noi, Hai Duong, and Bac Ninh are well developed. With such location, Yen My town has been seen as splendid place for the rice collecting and rice processing activities.

The paddy area for rice production of the district is 260 hectares; the area is in the decreasing trend in recent years. The average paddy area per capita is $258.7 \mathrm{~m}^{2}$. Land used for rice production occupies $96.7 \%$ of the total agriculture land, which is in decreasing trend due to rapidly urbanization, housing needs, and other new construction works (communal statistical office, 2002).

Yen My town consists of 5 villages: Trai Trang, Do Xa, Ong To, Dong La, and Nghia Trang with almost 3,000 households (table 1). Of that, farming households occupy $89.3 \%$, industrial and small industrial households $9.1 \%$, and servicing households $1.6 \%$. Since after renovation many non-farm activities have been developed in Yen My, such as transportation service, food processing, small rural industries. Those activities have created employment and increased income for households here. Ratio of high-income households is $30 \%$, medium-income $65 \%$, and low-income $5 \%$. Recent year the number of pure farming household has trend to decrease. Total labor force was reached to 7,300 persons in Yen My in 2001. Farming labor force occupied 81\%, small industrial labor force $15.7 \%$, and service labor force $3.3 \%$. The number of persons joining labor force still has trend of increase by year, however, the ratio of agricultural labor force has been decreasing (Communal statistical office, 2002).

\section{Socio-economic situation of rice based farming system in Yen My}

Of the 30 rice-growing households, we selected 9 in high-income group, 15 in medium-income group, and 6 in low-income group. Of the 35 rice-milling households, we chose 9,15 and 11 large-scale, medium-scale and small-scale plant, respectively.

\subsection{Rice-growing households}

Some characteristics of the household head including the age, gender, education level, years of experience and household income are presented in table 2. As seen in the table 2 the age of the head of household ranged from 40.2 to 46.4 with average of 42.8 years. Even both man and woman worked together in farming activities, but the man plays the main role in making decision in the family. The ratio of male as household head is accounting for $87.42 \%$, while this figure for women only $12.58 \%$. 
Table 2. General information of rice-growing household

\begin{tabular}{lccccc}
\hline \multicolumn{1}{c}{ Indicator } & Unit & $\begin{array}{c}\text { High income } \\
\text { HH }\end{array}$ & $\begin{array}{c}\text { Medium } \\
\text { income HH }\end{array}$ & $\begin{array}{c}\text { Low income } \\
\text { HH }\end{array}$ & Average \\
\hline 1. Age of HH head & Year & 46.4 & 41.5 & 40.2 & 42.8 \\
2. Gender of HH head & $\%$ & 89.34 & 82.13 & 90.75 & 87.42 \\
- Male & $\%$ & 11.66 & 18.87 & 9.25 & 12.58 \\
- Female & $\%$ & 32.16 & 39.48 & 48.09 & 39.55 \\
3. Education attainment of HHH & $\%$ & 57.63 & 55.73 & 51.91 & 54.28 \\
- Primary school & $\%$ & 10.21 & 5.79 & - & 6.17 \\
- Secondary school & $\%$ & - & - & - & - \\
- High school & year & 25.19 & 21.08 & 19.73 & 22.56 \\
- University & $\%$ & 10.56 & 20.82 & 35.53 & 20.68 \\
4. Farming experience of HHH & $\%$ & 20.05 & 25.04 & 25.68 & 23.67 \\
5. Income structure of HH & $1000 \mathrm{VND} /$ year & 15564.29 & 8947.35 & 5839.47 & 10310.90 \\
- Crop production & $\%$ & 69.39 & 54.14 & 38.79 & 55.65 \\
- Livestock production & HH & 9 & 15 & 6 & 30 \\
- Others & $\%$ & & & & \\
Number of survey household & $\%$ & & & & \\
\end{tabular}

Source: Survey 2002 Note: HHH: household head HH: household

In general the literacy rate among farmers was low. Mostly household head attained only education level of primary and secondary school, the proportion of farmers attaining higher school and higher education were very small. This figure was found lowest in the low- income group. The low level of education was one of constraints that discourage farmers from adopting modern technologies and new agricultural knowledge.

The source of income of farming household was from agriculture accounting for $44.35 \%$, of which $20.68 \%$ from crop production and $23.67 \%$ from livestock production in average. However the structure of income source varied by groups. Only $30.56 \%$ of total income of households of high-income group earned from agriculture, but this figure of low-income group was $61.26 \%$. The rest of $55.65 \%$ of income was from other sources such as food processing, transportation, trade, hired labor.

The situation of land, family size and labor forces are presented in table 3. The

Table 3. Information on land, family size and labor force of rice growing household

\begin{tabular}{lccccc}
\hline \multicolumn{1}{c}{ Indicator } & Unit & $\begin{array}{c}\text { High income } \\
\mathrm{HH}\end{array}$ & $\begin{array}{c}\text { Medium } \\
\text { income HH }\end{array}$ & $\begin{array}{c}\text { Low income } \\
\text { HH }\end{array}$ & Average \\
\hline I. Land holding & $\mathrm{m}^{2}$ & 1177.5 & 1070.37 & 1063.73 & 1092.69 \\
1. Rice land & $\mathrm{m}^{2}$ & 1082.50 & 1015.81 & 1002.94 & 1020.52 \\
2. Garden land & $\mathrm{m}^{2}$ & 42.2 & 33.4 & 30.1 & 35.38 \\
3. Pond & $\mathrm{m}^{2}$ & 20.1 & - & - & 6.03 \\
4. Other land & $\mathrm{m}^{2}$ & 32.70 & 28.16 & 30.69 & 30.76 \\
II. Member and labor & & & & & 4.69 \\
1. Family size & person & 4.81 & 4.64 & 4.57 & 4.69 \\
2. Number of labor & Person & 2.66 & 2.73 & 2.54 & 2.67 \\
\hline
\end{tabular}

Source: Survey 2002 
average area of rice production for each household is $1092.69 \mathrm{~m}^{2}$. The difference in land holdings of those three groups of household is unnoticeable since the land area used for rice-growing activities is assigned according to the number of member in each household. At Yen My district, the family size is slightly different among groups. It ranged from 4.57 to 4.81 persons with average of 4.69. High population and small area are also conditions contributing to development of non-farm and service activities such as rice milling and other food processing.

Some main assets for farming of rice growing households are reported in the table 4 . Assets of households for farming were rather poor. Most of farmers own only water pump and pesticide sprayer as some tools for farming. At Yen My district, Majority of households uses machines rented from the Agricultural Cooperatives or other households for land preparation and threshing. Therefore, buffaloes, cows, and manual rice threshing machines have no longer been used.

Table 4. Farming asset of rice growing household (unit: 1000VND)

\begin{tabular}{lcccc}
\hline \multicolumn{1}{c}{ Asset } & $\begin{array}{c}\text { High income } \\
\text { HH }\end{array}$ & $\begin{array}{c}\text { Medium } \\
\text { income HH }\end{array}$ & $\begin{array}{c}\text { Low income } \\
\text { HH }\end{array}$ & Average \\
\hline 1. Construction works & & & & \\
- House & 60,000 & 42,500 & 18,250 & 41,154 \\
- Yard & 4000 & 2950 & 1215 & 2918 \\
- Animal stable & 4250 & 3034 & 2129 & 3215.8 \\
- Other works & 10833 & 7500 & 3667 & 7458 \\
2. Water pump & 291.67 & 256.25 & 234.19 & 255.14 \\
3. Pesticide sprayer & 50.83 & 49.02 & 44.50 & 48.17 \\
4. Threshing machine & 1000 & - & - & 300 \\
4. Bicycle & 337.5 & 247.50 & 262.31 & 268.24 \\
5. Other transportation means- & - & - & - \\
6. Cash & 9562 & 6168 & 3605 & 6673.75 \\
\hline
\end{tabular}

Source: survey 2002

\subsection{Rice collectors}

The total number of collectors (collecting household) is five. Since the number is small, so we did not categorize them into groups. Information about age, gender, education level, years of experience of heads of households, and income structures are presented in table 5 .

The average age of heads of households is 39.82 years. The proportion of head of household being male is $88.17 \%$ and female $11.83 \%$. Head of collecting household attain higher education level compared to rice growing households. The proportion of those who graduated high school is $62.21 \%$, and those who only graduated primary school is $7.38 \%$. Most of farmers have started expanding their business during 1990-1995 with 8.64 year of experience. However, some of them had experienced as very small collectors at local area, so called "hang xao" in Vietnamese language for long time. The main sources of income are from collecting activity and other non-farm activities accounting for $71.35 \%$.

The average number of household members in each household is 4.41 persons with 
Table 5. General information of collecting household and milling and processing household

\begin{tabular}{|c|c|c|c|c|c|c|}
\hline \multirow[b]{2}{*}{ Indicator } & \multirow[b]{2}{*}{ Unit } & \multirow[b]{2}{*}{$\begin{array}{c}\text { Collecting } \\
\mathrm{HH}\end{array}$} & \multicolumn{4}{|c|}{ Milling and processing $\mathrm{HH}$} \\
\hline & & & $\begin{array}{c}\text { Large } \\
\text { scale }\end{array}$ & $\begin{array}{l}\text { Medium } \\
\text { scale }\end{array}$ & $\begin{array}{l}\text { Small } \\
\text { scale }\end{array}$ & Average \\
\hline $\begin{array}{l}\text { 1. Age of } \mathrm{HH} \text { head } \\
\text { 2. Gender of } \mathrm{HHH}\end{array}$ & Year & 39.82 & 42.17 & 44.09 & 41.86 & 42.59 \\
\hline - Male & $\%$ & 88.17 & 86.26 & 80.98 & 78.61 & 82.73 \\
\hline $\begin{array}{l}\text { - Female } \\
\text { 3. Education attainment }\end{array}$ & $\%$ & 11.83 & 13.74 & 19.02 & 21.39 & 17.27 \\
\hline - Primary school & $\%$ & 7.38 & 0 & 13.33 & 18.18 & 11.43 \\
\hline - Secondary school & $\%$ & 30.41 & 44.44 & 53.33 & 63.64 & 54.29 \\
\hline - High school & $\%$ & 62.21 & 55.56 & 33.33 & 18.18 & 34.28 \\
\hline - University & $\%$ & - & - & - & - & - \\
\hline 4. Experience & Year & 8.64 & 13.08 & 11.72 & 9.65 & 11.57 \\
\hline 5. Income of $\mathrm{HH}$ & $1000 \mathrm{~d} /$ year & 25583.74 & 55545.54 & 35412.65 & 28283.54 & 38349.1 \\
\hline - Crop production & $\%$ & 18.09 & 4.94 & 6.07 & 9.92 & 6.87 \\
\hline - Livestock production & $\%$ & 10.56 & 17.16 & 19.51 & 25.68 & 21.35 \\
\hline - Other & $\%$ & 71.35 & 74.12 & 70.83 & 61.41 & 69.66 \\
\hline & & & 3.78 & 3.59 & 2.99 & 3.47 \\
\hline Number of survey $\mathrm{HH}$ & $\mathrm{HH}$ & 5 & 9 & 15 & 11 & 35 \\
\hline
\end{tabular}

Source: Survey 2002 Note: HHH: household head HH: household

the average number of labor force is 1.79 persons. Due to requirement of many labors in the collecting activities, therefore, collectors usually have to hire labor with 2.13 labors as permanent labor and 2.86 labors as temporary labor during peak time. The data of family size and labor was presented in table 6 .

The capital resources and equipments are listed in the following table 7. For collectors, drying yard and warehouse are very important. Since the warehouses of those household is small and limited space therefore, many of them use part of their houses as warehouses for rice. But for those big collectors, they have their own warehouses. According to table 7, the average value of warehouse is $21,576,000 \mathrm{VND}$. Besides, they also own transportation means mainly trucks, tractors, and bicycles. Small trucks and car are used for long distance, transportation and collecting activities in distance. For

Table 6. Family size and labor force of collecting household and milling and processing household

\begin{tabular}{|c|c|c|c|c|c|c|}
\hline \multirow[b]{2}{*}{ Indicator } & \multirow[b]{2}{*}{ Unit } & \multirow[b]{2}{*}{$\begin{array}{c}\text { Collecting } \\
\mathrm{HH}\end{array}$} & \multicolumn{4}{|c|}{ Milling and processing $\mathrm{HH}$} \\
\hline & & & $\begin{array}{l}\text { Large } \\
\text { scale }\end{array}$ & $\begin{array}{l}\text { Medium } \\
\text { scale }\end{array}$ & $\begin{array}{l}\text { Small } \\
\text { scale }\end{array}$ & Average \\
\hline 1. Family size & Person & 4.41 & 5.66 & 5.34 & 5.09 & 5.28 \\
\hline $\begin{array}{l}\text { 2. Family labor force } \\
\text { 3. Hiring labor }\end{array}$ & Person & 1.79 & 2.32 & 2.81 & 3.06 & 2.83 \\
\hline - Permanent & Person & 2.13 & 2.95 & 2.17 & 1.98 & 2.37 \\
\hline - Temporary & Person & 2.86 & 3.76 & 2.24 & 1.77 & 2.91 \\
\hline
\end{tabular}

Source: survey 2002 
Table 7. Production asset of collecting household and milling and processing household

(unit: 1000VND)

\begin{tabular}{lccccc}
\hline \multirow{2}{*}{ Asset } & Collecting & \multicolumn{4}{c}{ Milling and processing HH } \\
\cline { 3 - 5 } & HH & Large-scale & Medium scale & Small scale & Average \\
\hline 1. Construction works & & & & & \\
- House & 61,154 & 87104 & 79,365 & 45,471 & 75,138 \\
- Back yard & 6,547 & 5206 & 4311 & 3,079 & 4019 \\
- Animal stable & 9,721 & 12795 & 10,508 & 7,188 & 10,124 \\
- Other works & 17,836 & - & - & - & - \\
2. Rice storehouse & 21,576 & 26417 & 20,116 & 13,790 & 19,884 \\
3. Truck and car & 150,911 & 152,128 & - & - & - \\
4. Bicycle & 325 & 421.3 & 389.6 & 310.07 & 391.06 \\
5. Other means & 12,089 & 17,608 & 13,191 & - & 16,085 \\
6 Milling machine & & 22149 & 14741.37 & 12045.63 & 16954.36 \\
7 Polishing machine & & 62,500 & - & - & - \\
8. Capital in cash & 68,314 & 80,540 & 60,250 & 30,380 & 56,174 \\
\hline
\end{tabular}

Source: Survey 2002

collecting activities in local area, the main transportation mean is bicycle. Yen My district has a quite modern network of transportation. Therefore, it is great advantageous for collectors to rent transportation means. Compared with that of the rice-growing households, collectors usually have much bigger average of capital investments and resources.

\subsection{Rice Milling and Processing households}

Heads of those households are mostly male as the same as rice growing and collecting households with the proportion of $82.73 \%$. The highest level of attained education of household head is high school. The large-scale milling and processing plants have the highest ratio of high school attendance, $55.56 \%$, and the lowest high school attendance rate of $18.18 \%$ is found at the small-scale milling and processing households. The average years of experience are also highest for those households with large-scale rice milling and processing plants. Table 5 shows that the main source of income of those households from rice milling with the proportion of $69.66 \%$. The income from agriculture especially from crop production just made up a small proportion of $28.22 \%$. However, income from livestock production of those households is relatively high accounting for $21.35 \%$ in average since these household can use some by-product such as bran, husk of processing activities for poultry and pig breeding. This shows the good combination between rice processing and development of animal breeding. Households with large-scale plants obtained highest income compared with those of small and medium-scale households.

Table 6 shows the current situation of household member and labor force. The average size of household is 5.28 persons. Households with small scale have the highest numbers of family labor force with 3.06 persons. In many cases, many family labors involving in off-farm are working in the city. Therefore, those households have to hire labor, and it is found that the ones with bigger plants will have to hire more labor. The 
average number of permanent hired labor force is 2.37 persons at normal seasons and 2.91 at peak seasons. They get paid either daily or monthly. Wage rate of hired labor is around 15,000-20,000 VND/day depending on the type of work.

Of all of them, the most valuable asset is the house, and it also often used as warehouse. The main transportation means are small trucks and bicycle. Of 35 households that we interviewed, there are only five households, which also participate in collecting activities besides the milling activities. They are always households with large-scale of plants. The rest of them ( 30 households) mainly provide only the rice milling services. They are usually households with medium and small-scale plants. Main equipments used are rice husking, milling, and polishing machines. The average value of a milling machine is $16,954.360$ VND. Each household can equip themselves with husking and milling machines, but polishing machine since it is very expensive. For those households equipped with rice polishing machine, they are usually the rich households with large-scale plants, and their products are always prepared for export. All information is presented in the table 7

\section{Current situation of rice production and processing \\ 4.1 Rice Production}

The total area for annual crop of Yen My are 236.88 hectares, and it is mainly devoted for rice. There are two main rice seasons that are spring rice season (Vu Xuan) and summer rice season ( $\mathrm{Vu} \mathrm{Mua}$ ). Besides, farmers also grow various crops such as vegetables, beans, potatoes, soybean, and corns. The soil is used efficiently, with coefficient of land use intensity of 2.3 per year. With the current soil and weather, the main rice varieties used are Chinese hybrid such as $Q_{4}, Q_{5}$, Khang Dan, and glutinous rice TK90. The main reason for using such rice varieties is high and stable yield for Chinese hybrid varieties and high selling price for glutinous and high quality ones.

For both Vu Xuan and Vu Mua season, high-income households devoted main area for glutinous rice TK90 with about $41.09 \%$ and $41.96 \%$ of their growing area while these figures in medium and low- income households only $36.46 \%, 39.75 \%$ in Vu Xuan and $25.53 \%$ and $20.69 \%$ in Vu Mua, respectively (table 8).

Besides the survey on types of variety, we also surveyed and calculated average rice yield regarding to different varieties in two seasons in year 2001 as presented in table 9 . Table 9 shows that the average yield of rice (paddy) of high income household is found highest compared to two other groups, however, the difference is not very much significant in yield among those types of households. The $Q_{5}$ variety has the highest yield for

Table 8. Share of rice growing area by rice variety (unit: \%)

\begin{tabular}{|c|c|c|c|c|c|c|c|c|}
\hline & \multicolumn{4}{|c|}{ Spring crop } & \multicolumn{4}{|c|}{ Summer crop } \\
\hline & $\mathrm{Q}_{4}$ & $Q_{5}$ & TK90 & Others & $\mathrm{Q}_{4}$ & $\mathrm{Q}_{5}$ & TK90 & Others \\
\hline 1. High income & 20.14 & 31.92 & 41.09 & 6.85 & 24.02 & 26.99 & 41.96 & 7.03 \\
\hline 2. Medium income & 25.05 & 38.49 & 36.46 & - & 27.19 & 40.41 & 25.53 & 6.87 \\
\hline 3. Low income & 12.24 & 48.01 & 39.75 & - & 35.87 & 43.44 & 20.69 & - \\
\hline
\end{tabular}

Source: survey 2002 
Table 9. Average yield of paddy (Unit: $k g / h a)$

\begin{tabular}{lccccccc}
\hline \multirow{2}{*}{ Type of HH } & \multicolumn{3}{c}{ Spring crop } & & \multicolumn{3}{c}{ Summer crop } \\
\cline { 2 - 3 } \cline { 7 - 8 } & $\mathrm{Q}_{4}$ & $\mathrm{Q}_{5}$ & TK90 & & $\mathrm{Q}_{4}$ & $\mathrm{Q}_{5}$ & TK90 \\
\hline 1. High income & 5003.1 & 5135 & 4970.7 & & 4897.8 & 5027.4 & 4857.3 \\
2. Medium income & 4997.7 & 5113.8 & 4954.5 & & 4892.4 & 5016.6 & 5854.6 \\
3. Low income & 4989.6 & 5084.1 & 4946.4 & & 4876.2 & 4951.8 & 4838.4 \\
Average & 4997.8 & 5116.5 & 4957.2 & & 4892.4 & 5011.2 & 4843.8 \\
\hline
\end{tabular}

Source: survey 2002

Table 10. Cost of paddy cultivation in VND per hectare (unit: $1000 \mathrm{VND} / \mathrm{ha}$ )

\begin{tabular}{lccccccccc}
\hline \multirow{3}{*}{ Cost item } & \multicolumn{4}{c}{ Spring crop } & & \multicolumn{4}{c}{ Summer crop } \\
\cline { 2 - 3 } & $\begin{array}{c}\text { High } \\
\text { incom }\end{array}$ & $\begin{array}{c}\text { Medium } \\
\text { income }\end{array}$ & $\begin{array}{c}\text { Low } \\
\text { income }\end{array}$ & Average & & $\begin{array}{c}\text { High } \\
\text { income }\end{array}$ & $\begin{array}{c}\text { Medium } \\
\text { income }\end{array}$ & $\begin{array}{c}\text { Low } \\
\text { income }\end{array}$ & Average \\
\hline Family labor & 810 & 3131 & 4320 & 2673 & & 810 & 3132 & 4200 & 2649 \\
Hired labor & 3740 & 1512.5 & 337.5 & 1948.75 & & 3625 & 1500 & 337.5 & 1905 \\
Material & 2029 & 2108.9 & 2103.3 & 2083.81 & & 1959 & 2047.5 & 2032.5 & 2017.95 \\
Rent machine & 931.5 & 1175.5 & 1174.5 & 1001.6 & & 913.5 & 1174.5 & 1175.5 & 1096.2 \\
Others & 810 & 810 & 810 & 810 & & 810 & 810 & 810 & 810 \\
Total & 8330.5 & 8737.9 & 8745.3 & 8617.16 & & 8117.5 & 8664 & 8554.5 & 8478.15 \\
\hline
\end{tabular}

Source: survey 2002

both $\mathrm{Vu}$ Xuan and $\mathrm{Vu}$ Mua. In general, rice yields of every variety are higher for Vu Xuan than Vu Mua. Non-sticky rice has attained higher yield than glutinous rice. However, some households still grow glutinous rice with 90 to $100 \%$ of their sowing area since it can be sold with higher price than that of non-sticky rice.

As shown in table 10, the average cost to grow rice per hectare is 8617.16 thousand VND and 8478.15 thousand VND for "Vu Xuan" and "Vu Mua" respectively. In "Vu Mua", most farmers do not use potash therefore the total cost is slightly less than that of "Vu Xuan". However, we notice that there is almost similar in the investments of households for the rice production. Taking the expenditure of spring rice as an example, the total cost for one hectare of paddy is 8330.5 thousand VND, 8737.9 thousand VND and 8745.3 thousand VND for high, medium and low-income group, respectively. However, the cost structure between main cost items like family labor, hired labor, material, rent machine and other costs varied by groups. Regarding to labor cost, high-income group used hired labor than family labor while the low-income group use mainly their family labor. For high-income household some activities such as rice transplanting, caring, harvesting, threshing, and transportation are all done by hired labor.

At Yen My town, the labor wage rate for rice transplanting and harvesting is attractive ranging from 20,000 dong to 25,000 dong/man-day. Comparing with that of other areas in the Red River Delta it is about 5000 dong/man-day higher. Then when calculating the family labor expenditure we used the local wage rate, and it made the total cost much higher. The expense for land preparation, tax, and irrigation fee are almost the same for 
all households since the cultivated area of households are not much different and those fees are calculated based on a local measurement "sao" $\left(1 \mathrm{sao}=360 \mathrm{~m}^{2}\right)$. One hundred percent of households except of some in high-income group use tractors for land preparation provided by agricultural cooperatives. The charge of preparing the land is 25,000 dong/sao or 675,000 dong/hectare. The cost of rice seeds is ranging from 3,500 dong to $4,000 \mathrm{dong} / \mathrm{kg}$, and that of glutinous rice seeds is ranging from 4,800 dong to 5,000 dong $/ \mathrm{kg}$. Almost households use threshing service and do threshing at the rice field soon after harvesting, then after that they just carry paddy back to their house.

Information on the cost of production and return of rice per one hectare was calculated, shown in table 11. The gross return varies by season and group of farmer. It obtains the higher value on spring season than those in summer season. Due to better yield earned and higher selling received therefore, high income household attains higher net return.

Table 11. Production cost and return of rice per 1 hectare (Unit: 1000VND)

\begin{tabular}{|c|c|c|c|c|c|c|c|c|}
\hline \multirow[b]{2}{*}{ Cost item } & \multicolumn{4}{|c|}{ Spring crop } & \multicolumn{4}{|c|}{ Summer crop } \\
\hline & $\begin{array}{l}\text { High } \\
\text { incom }\end{array}$ & $\begin{array}{l}\text { Medium } \\
\text { income }\end{array}$ & $\begin{array}{c}\text { Low } \\
\text { income }\end{array}$ & Average & $\begin{array}{l}\text { High } \\
\text { income }\end{array}$ & $\begin{array}{l}\text { Medium } \\
\text { income }\end{array}$ & $\begin{array}{l}\text { Low } \\
\text { income }\end{array}$ & Average \\
\hline Total cost & 8330.5 & 8737.9 & 8745.3 & 8617.16 & 8117.5 & 8664 & 8554.5 & 8478.15 \\
\hline Revenue & 10470.8 & 9852.26 & 9546.93 & 9976.76 & 9552.25 & 8938.26 & 8804.7 & 9095.75 \\
\hline Net return & 2140.3 & 1114.36 & 801.63 & 1359.59 & 1434.75 & 274.26 & 250.2 & 617.6 \\
\hline $\begin{array}{l}\text { Return (including } \\
\text { family labor) }\end{array}$ & 2950.3 & 4246.36 & 5121.63 & 4032.59 & 2244.75 & 3406.26 & 4450.2 & 3266.59 \\
\hline Cost per unit $(\mathrm{d} / \mathrm{kg})$ & 1591.19 & 1685.09 & 1694.66 & 1658.61 & 1614.62 & 1744.77 & 1748.85 & 1706.07 \\
\hline $\begin{array}{l}\text { Cost per unit } \\
\text { (excluding family } \\
\text { labor) }\end{array}$ & 1436.67 & 1081.09 & 857.53 & 1144.12 & 1453.51 & 1114.04 & 890.22 & 1173.01 \\
\hline
\end{tabular}

Source: survey 2002

After harvesting, households keep only a small amount of rice for their usage; the rest is sold within one or two months. Sometimes they themselves transport rice to the market to sell, but usually collectors and rice millers (or processors) come and buy all (Figure 1). The selling process is based on the agreement between the sellers and the buyers. According to respondents of 30 rice-growing households when asked that what the main factor in pricing are, $100 \%$ answered that the price of rice is based on two main factors, the market prevailing price and the quality of rice.

Agricultural Cooperatives of the district provides for its members with three services: seeds, fertilizers, and irrigation. Of the 30 households interviewed, 21 of them (70\%) say the Agricultural Cooperative providing good services, while 9 of them (30\%) say the service still needs to be improved. Irrigation is considered very important and requites large investment in constructing irrigation system, so that individual household cannot service on its own. Most of households are satisfied with the service of irrigation and supplying seeds. Other commercial services of the Agricultural Cooperatives are facing hardship and tough competition with those services of private sectors. 


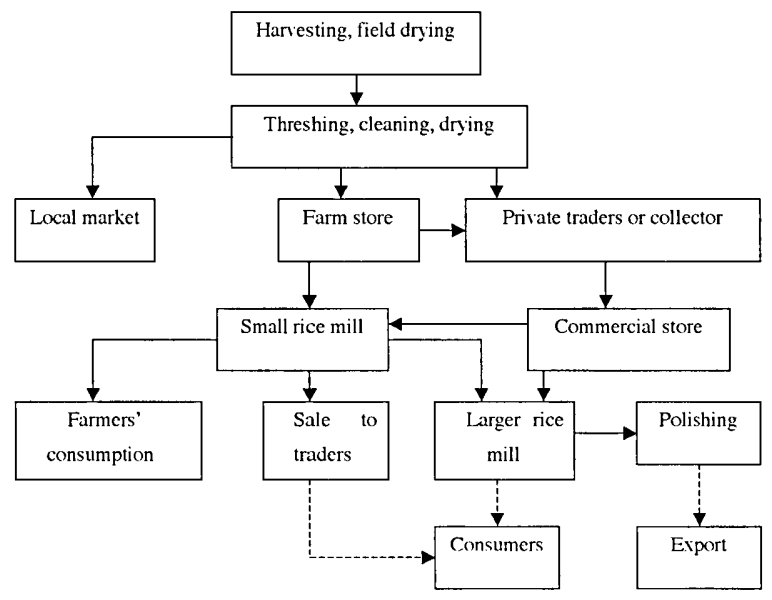

Fig. 1. Post harvest system of paddy/rice

Of the 30 rice-growing households interviewed, there are 17 households or $56.57 \%$ reported to use credit loan. Of those households, 9 or $52.94 \%$ borrow money from the Agriculture Bank, 6 or $35.29 \%$ borrow from farmer association, and 2 or $11.77 \%$ borrow from Bank for the poor. The average borrowing quantities are $10.52 \mathrm{mil}$ VND, $7.28 \mathrm{mil}$ VND, and 3.04 mil VND per household for high-income, medium-income and low-income households, respectively. The interest rate is approximately $1 \%$ per month for formal credit and 5\% per month for informal one; and the duration of the loan is usually one year. The main usage of loan is to buy fertilizers and to payback old debts. In general, the credit system at the local area improved and provide better service, but most of households still consider that the available funds is short for needs and lending procedures are complicated.

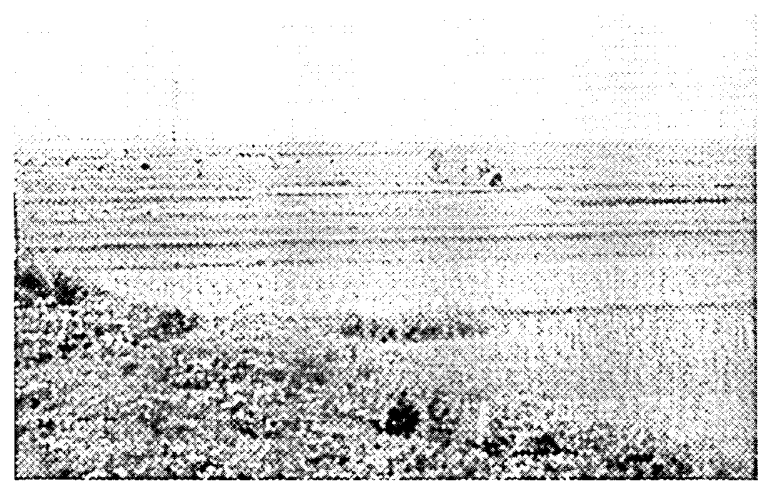

Picture 1. Rice field with small and scattered plots 


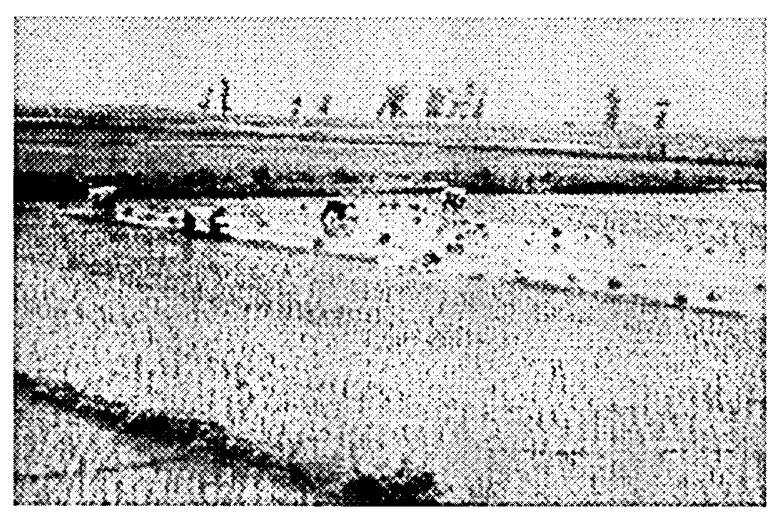

Picture 2. Rice transplantation

\subsection{Collectors}

At Yen My town, collecting households mainly use trucks, tractors, and bicycles to support their rice collecting activities. They not only buy rice from the local area, but also cover the buying services in other provinces such as Nam Dinh, Thai Binh, Ninh Binh, Hue, and some provinces in the South of Vietnam.

The means used for transportation depend on the distance, capacity, and capital resources of each household. Table 12 shows the situation of activities of the five collecting households interviewed. In average, each household bought 770.5 tons and 906.5 tons of paddy and white rice annually, respectively. Most of the paddy and white rice are from their own provinces and from the provinces of the South. Table 15 shows that $26.89 \%$ and $37.54 \%$ of paddy is bought from Hung Yen province and from the provinces in the South respectively. About $31.58 \%$ and $33.03 \%$ of white rice are purchased from Hung Yen province and the provinces of the South respectively. The cost of collecting rice from its own province is less due to minimal transportation cost. The paddy and white rice from the provinces in the South are usually better in quality with copious types of varieties, and cheaper. Those are reasons why rice from the South is bought in greater quantity even though transportation fee is higher.

Since access to formal information about the rice market in Vietnam is still limited

Table 12. Rice collecting activity of household (unit: ton/household)

\begin{tabular}{lcccr}
\hline \multicolumn{1}{c}{ Province } & $\begin{array}{c}\text { Total volume of } \\
\text { paddy }\end{array}$ & Ratio (\%) & $\begin{array}{c}\text { Total volume of } \\
\text { white rice }\end{array}$ & Ratio (\%) \\
\hline Total & 770.50 & 100.00 & 906.50 & 100.00 \\
1. Local area & 207.20 & 26.89 & 286.30 & 31.58 \\
2. Nam Dinh & 81.10 & 10.52 & 110.50 & 12.18 \\
3. Thai Binh & 93.60 & 12.14 & 98.70 & 10.88 \\
4. Ninh Binh & 50.70 & 6.58 & 61.20 & 6.57 \\
5. Hue & 48.80 & 6.33 & 50.60 & 5.58 \\
6. The South & 289.10 & 37.54 & 299.20 & 33.03 \\
\hline
\end{tabular}

Source: survey 2002 
due to many reasons, therefore such informal source like friends and partnerships in local area and provinces are good sources providing information on the supply and demand of rice consuming market. The price is set based on negotiation between the buyers and sellers. There are two main factors in setting the price that are the prevailing market price and the quality of rice.

Sometimes rice is sold immediately after collecting. However, sometimes rice has to be put into warehouse. The duration for white rice or paddy to be kept in the warehouse depends on the fluctuation of price market risk and capital sources of the collectors to cope with the risk. The storing method is that rice simply put into bag and stored in the warehouse. The warehouse storing capacity is 31.6 ton.

Paddy and white rice will be sold back to wholesalers, rice milling and processing households, or buying agencies of the government. In many cases, collecting households are also participated in rice milling and processing activities.

Of the 5 collecting households studied, all are involved in some sources of financial credit. They borrow money from the Agriculture and Rural Development Bank, Commercial Bank, and merchants. The average loan is 75 to 80 millions VND. Interest rate is normally at $1.2 \%$ per month for formal credit and much higher (about 5-7\%) for informal one. The duration for loan is usually for one year. The main purpose of the loan is to upgrade the transportation equipments, to repair or build new warehouses, and to finance for the rice collecting process.

According to the local people, the interest rate is reasonable. However, they need more financial resources and long-term borrowing duration. Therefore, we can say the two main obstacles for those collectors at Yen My district are restriction of financial resources and lack of information.

\subsection{Rice Milling and Processing}

Of the total 35 rice milling and processing households, there are only five households, which also participate in the rice collecting services (abbreviated as collecting M.P. households). The rest are involved only in rice milling and processing services. In order to meet the standard of export, rice for export must always go through the polishing process.

Collecting M.P. households purchase white rice and paddy from various areas. Besides the local area (Hung Yen province), they also buy paddy and white rice from other provinces such as Nam Dinh, Thai Binh, the provinces in the south and other

Table 13. Paddy collecting activity of collecting M.P. household

Unit: ton/household

\begin{tabular}{lcc}
\hline \multicolumn{1}{c}{ Province } & Paddy volume & Ratio (\%) \\
\hline Total & 644.2 & 100.00 \\
1. Local area & 196.87 & 30.56 \\
2. Nam Dinh & 82.09 & 12.74 \\
3. Thai Binh & 87.54 & 13.58 \\
4. The South & 231.92 & 36.01 \\
5. Other provinces & 45.78 & 7.11 \\
\hline
\end{tabular}

Source: survey 2002 
regions. Table 13 shows the volume of collected paddy in 2001 . Two areas with highest purchased volume are provinces in the south and local area (Hung Yen province) with 231.92 ton $(36.01 \%)$ and 196.87 ton $(30.56 \%)$, respectively. The main transportation means are truck, tractor and bicycle.

The capacity of rice milling and processing as seen in the table 14 is quite difference among groups of households. Milling capacity in average per year of large scale, medium scale and small scale plant is 3666.67 ton, 1666.75 ton and 1139 ton, respectively. However, the efficiency rate of each type of plant also varied. At top efficiency rate bracket, the capacity is 38.5 tons/day for households with large-scale plants, and only 8.18 tons/day for households with small-scale plants. At the medium efficient rate bracket, the capacity is 11.67 tons/day and 4.09 tons/day for large-scale and small-scale, respectively. At the lowest efficient rate basket the capacity is only 4.17 ton/day and 0.5 ton/day ton for large scale and small scale. In general, they work all year round, but the busiest season is always just after the harvesting season. As also seen in the table, almost milling machines of 3 groups still have not exploited in full capacity. Several reasons explained for this problem are as follow: firstly, due to capital shortage; Because of lacking of capital, so households could not purchase large volume of paddy and rice. Secondly, lack of space for storing and keeping rice.

Table 14. Milling capacity of milling and processing household

\begin{tabular}{lccc}
\hline \multirow{2}{*}{ Capacity } & \multicolumn{3}{c}{ Paddy volume } \\
\cline { 2 - 4 } \multicolumn{1}{c}{ Large scale } & Medium scale & Small scale \\
\hline 1. Highest & 38.5 & 12.38 & 8.18 \\
2. Medium & 11.67 & 7.29 & 4.09 \\
3. Lowest & 4.17 & 1.89 & 0.5 \\
Milling capacity per year & 3666.67 & 1666.75 & 1139 \\
\hline 90-100\% capacity & 155 & 103.85 & 110.29 \\
$70-89 \%$ & 95 & 110.91 & 71 \\
50-69\% & 115 & 99.55 & 83.33 \\
30-49\% & 90 & 91.1 & 76 \\
Less than 30\% & - & 44.59 & - \\
\hline
\end{tabular}

Source: survey 2002

Table 15 shows the storage capacity of households. Most of households don't have enough space for storing rice. They usually have to use their living house as rice store house. Lack of good condition and measures for storing and maintaining, therefore rice can not be kept for long time, especially in the rainy and humidity season. Due to lacking of capital, and space, so the holding period also can not last longer to more than 1 month.

There is no difference in service charges for milling and polishing among groups of household. Table 16 shows the breakdowns of service charges for milling of one ton of paddy. According to table 16 the service charges are mainly involved with the labor and fuel/electricity costs. Labor cost accounts for over $47.3 \%$, and fuel/electricity $24 \%$ of service charges.

For those households, which involved in paddy collecting activity (collecting M.P 
Table 15. Storage capacity

\begin{tabular}{lcc}
\hline \multicolumn{1}{c}{ Type of HH } & Capacity (ton) & Holding period (day) \\
\hline Collecting HH & 31.6 & $1-7(2.0)$ \\
Small scale milling HH & 35.5 & $2-7(2.3)$ \\
Medium scale milling HH & 51.04 & $7-16(7.5)$ \\
Large scale milling HH & 80 & $5-30(12.5)$ \\
\hline
\end{tabular}

Source: survey 2002

Table 16. The charge of milling service (unit: $1000 \mathrm{VND} / \mathrm{kg}$ )

\begin{tabular}{lcc}
\hline \multicolumn{1}{c}{ Item } & Structure of total cost & Ratio (\%) \\
\hline Total cost & 63.42 & 100.00 \\
1. Labor cost & 30 & 47.30 \\
2. Electricity, petrol cost & 15.82 & 24.94 \\
3. Depreciation & 3.6 & 5.68 \\
4. Other costs & 5 & 7.88 \\
\hline
\end{tabular}

Source: survey 2002

households), they usually buy paddy from collectors or deal directly with rice growers. Price setting process is based on negotiation between buyer and seller. As normal, the price depends on the supply and demand of rice in the market and quality of rice. Four of 5 interviewed large-scale households, accounting for $80 \%$, answer that they could get accurate information on rice price in the market.

Before milling, paddy is graded according to rice varieties and quality. The average capacity of their warehouse is 80 tons, and they always have paddy in reserve from one week to one month. According to the five households with paddy collecting activity (collecting M.P. household), $70 \%$ of total white rice volume is sold for wholesaler, $20 \%$ for retailers, and the rest of $10 \%$ for government agencies.

Total cost for one ton of white rice is 2899.78 thousand VND of which the cost for buying paddy occupies $93.69 \%$ as shown in table 17 . After milling and polishing, the

Table 17. Milling cost of 1 ton of rice (unit: 1000VND/ton)

\begin{tabular}{lcc}
\hline \multicolumn{1}{c}{ Item } & Quantity & Ratio (\%) \\
\hline Total cost & 2899.78 & 100 \\
Paddy purchase & 2714.28 & 93.69 \\
Transportation cost & 100 & 3.49 \\
Loading/unloading cost & 10 & 0.35 \\
Electricity, oil and fuel & 15.5 & 0.53 \\
Labor & 40 & 1.4 \\
Depreciation & 10 & 0.35 \\
Sack cost & 5 & 0.18 \\
Other & 5 & 0.18 \\
\hline
\end{tabular}

Source: survey 2002 
weight conversion ratio between paddy and white rice is about $70 \%$. Other by-products such as husk and bran are returned to customers. According to assessment of local government leaders and heads of households, milling and polishing equipments are fairly new and modern.

According to observation and study, two main obstacles for rice milling and processing households are shortage of electricity and restriction of surface area used for production. Many households want to expand the surface area of production and build new warehouses, but there is no land available. Besides, each household is bound by certain amount of electricity for usage in production. Some households want to invest in more equipment, but they are faced with shortage of electricity. If they use more electricity for equipment, it will lead to the long-term disruption of electric power since the power line is old. Therefore, the capacity of power line is another major obstacle and should be addressed first in order of priority.

In addition, there are other issues should be pay attention such as dirt, dust coming from the rice milling and polishing process, noise, and environment pollution. They affect the life of many people.

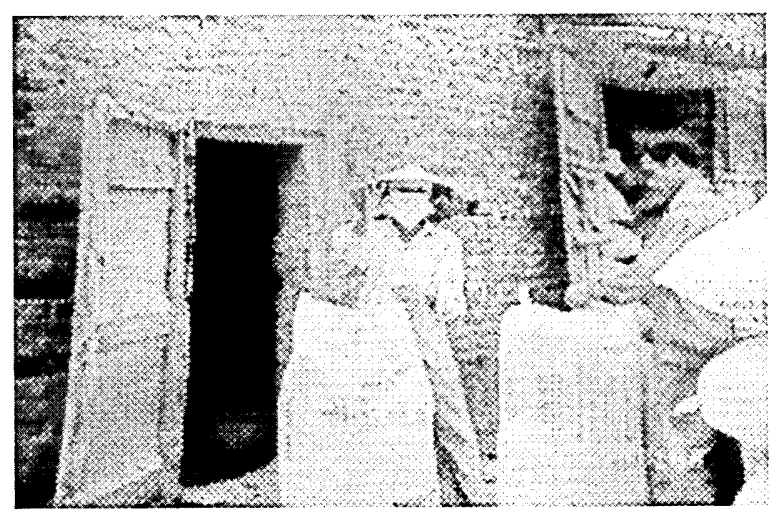

Picture 3. At the small rice mill

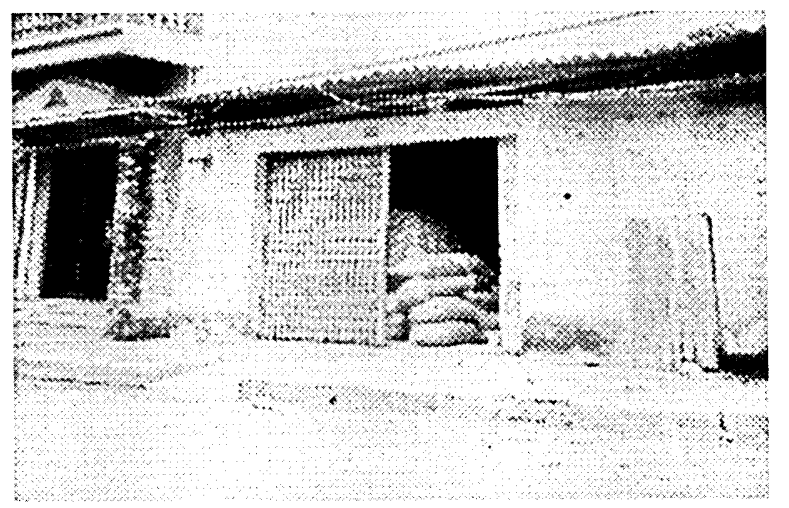

Picture 4. The poor condition of warehouse 


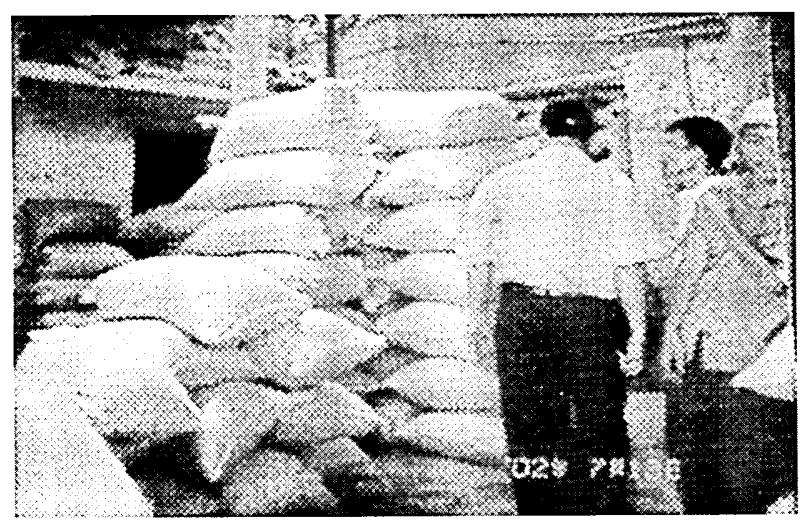

Picture 5. rice is stored in sacks

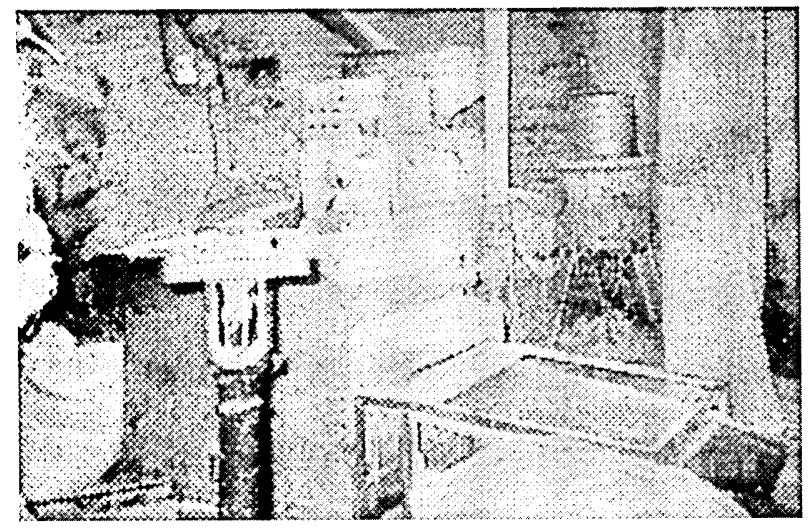

Picture 6. Rice milling machine

\section{Conclusion}

Eventful trading and processing activities in Yen My reflected the gradual change in restructuring of agriculture of North Vietnam toward to diversified and sustainable agriculture in stead of pure one as previous period before renovation. For coming future, food crops and rice are still dominant cops in Red River Delta, however, the income from rice is very low and rice production in the North has less comparative advantage than that in the Mekong Delta. Main problems for rice growing farmer could be small and scattered land holding, high input price, and inefficiency of supporting organizations as well. Therefore, increase of production efficiency is one solution for rice production in the North, on the other hand, promotions of off-farm job and industry in rural are long-term strategies.

Rice collecting and processing households play very important roles in creating the 
large marketing network, making bridge between the producers and consumers, narrowing the price gaps between the Mekong Delta and the North. They operate on quite large region, not only in the north, but other provinces of the Mekong Delta also. Thanks to those trading and processing activities, income of households have been improving and creating more employment in rural area. However, the common obstacles of collecting group are shortage of capital, limited access to credit and market information. For processing household main problems are: restriction of financial resources, too short duration term of loan, poor in information about the rice market, restriction of capacity of power line, or poor rural infrastructure and narrow surface area used for production.

The policy of diversified agriculture, combination of farming and non-farm activities should be promoted in order to improve farmers' income. The condition, procedure for loan should be improved so that more farmers could get access to formal credit. Activity of supporting organizations in rural area, especially extension organization, and new style cooperative should be improved to provide better service and meet the requirement of farmers on new agricultural knowledge and modern technology. Infrastructure in rural area should be upgraded to create the good conditions for processing industry development. Post harvest improvement is very necessary. The Government should promote an environment conducive to the private sector investment in post-harvest system. Storage facilities at the household level should need to be developed.

\section{REFERENCES}

Communal Statistical Office of Yen My 2002 General Statistical Data of Yen My Town. Department of Statistics of Hung Yen Province, Hung Yen.

General Statistical Office 2000 Statistical Year Book 1999. General Statistical Office, Hanoi

Izumida, Y., Shindo, S. and Pham B. D. 2002 Restructuring of Agriculture in Vietnam- The Present State and Problem to be solved. Working Paper Series, Dept. of Agric. and Resource Economics, The University of Tokyo, No. 02-F-03: 1-26 (In Japanese)

Kawaguchi, Tsunemasa 2003 Transformation of Marketing System of Farm Household Products in the Course of Restructuring of Agriculture in Vietnam and Problems to be solved to Modernize the System. In "Report of Research Project, Grant-IN-AID for Scientific Research (B) (2) Project number 12572032", ed. by Masao Tsuji, Faculty of Agricultural, Kyushu University (In Japanese), PP. 58-70 and 197-237 